\title{
Phytochemical Constituents from the Flowers of Gymnaster koraiensis and Their Cytotoxic Activities in vitro
}

\author{
Il Kyun Lee, Ki Hyun Kim, Shi Yong Ryu, ${ }^{\dagger}$ Sang Un Choi, ${ }^{\dagger}$ and Kang Ro Lee ${ }^{*}$ \\ Natural Products Laboratory, College of Pharmacy, Sungkyunkwan University, Suwon 440-746, Korea \\ *E-mail:krlee@skku.ac.kr \\ ${ }^{\dagger}$ Research Institute of Chemical Technology, Teajeon 305-600 \\ Received September 10, 2009, Accepted November 30, 2009
}

Key Words: Gymnaster koraiensis, Sesquiterpene glucopyranoside, Polyacetylene, Cytotoxicity

Gymnaster koraiensis (Nakai) Kitamura (Compositae) is widely distributed in the northern parts of Korea. This indigenous herb is used as a folk medicine for antitussive and antibacterial activities. ${ }^{1}$ Previous phytochemical studies on this plant showed the presence of polyacetylenes, and benzofurans. ${ }^{2,3,4}$ We have recently reported the isolation of sesquiterpenes and flavonoids from this plant. ${ }^{5}$ In a continuing study on this source, we have further isolated two new sesquiterpene glucopyranosides (1-2), together with ten known compounds (3-12) by repeated column chromatography of the EtOH extract. Compounds 3-12 were identified as gymnasterkoreayne B (3), ${ }^{3}$ gymnasterkoreayne E (4), ${ }^{3}$ gymnasterkoreayne $\mathrm{F}(\mathbf{5}){ }^{3} 1,9(Z)$, 16-heptadecatriene-4,6-diyne-3,8-diol (6), ${ }^{3,6}$ apigenin (7), ${ }^{7}$ naringenin (8), ${ }^{8,9}$ apigenin-3-O- $\beta$-D-glucopyranoside (9), ${ }^{10}$ quercetin-3- $O$ - $\beta$-D-glucopyranoside (10), ${ }^{10}$ isorhamnetin-3- $O-\beta$-Dglucopyranoside (11), ${ }^{12}$ apigenin-3-O- $\beta$-D-glucuronide (12) ${ }^{7}$ by comparing the ${ }^{1} \mathrm{H}-\mathrm{NMR},{ }^{13} \mathrm{C}-\mathrm{NMR}$, and mass spectral data with the literature data. Compounds 7-12 were isolated from this plant for the first time. The isolated compounds were tested for their cytotoxicity against four human tumor cell lines in vitro using the SRB assay.

Compound 1 was obtained as colorless gum with a molecular formula of $\mathrm{C}_{21} \mathrm{H}_{36} \mathrm{O}_{8}$ from the $[\mathrm{M}+\mathrm{Na}]^{+}$peak at $\mathrm{m} / \mathrm{z} 439.2306$ (calcd. for $\mathrm{C}_{21} \mathrm{H}_{36} \mathrm{O}_{8} \mathrm{Na}:$ 439.2308) in the positive-ion HRFABMS. The IR spectrum indicated that 1 possessed a hydroxyl $\left(3386 \mathrm{~cm}^{-1}\right)$ group and a $\mathrm{C}=\mathrm{C}$ double bond $\left(1650 \mathrm{~cm}^{-1}\right)$. In the ${ }^{13} \mathrm{C}$-NMR (including DEPT) spectrum, 21 carbon signals appeared, which included four methyl carbons at $\delta_{\mathrm{C}}=21.9,21.9$, 21.8 and 9.3 , two methylene carbons at $\delta_{\mathrm{C}}=32.6$ and 30.8 , three oxygenated methine carbons at $\delta_{\mathrm{C}}=81.3,79.6$ and 76.6, two olefinic carbons at $\delta_{\mathrm{C}}=136.4$ and 120.6 , three methine carbons at $\delta_{\mathrm{C}}=52.1,51.9$ and 28.9 , one quaternary carbon at $\delta_{\mathrm{C}}=42.4$, and six signals assignable to the glucose moiety $\left(\delta_{\mathrm{C}}=\right.$ 104.6, 78.4, 77.3, 76.1, 72.1, and 63.4). These data indicated that compound 1 was a eudesmane type sesquiterpene glucopyranoside. ${ }^{13}$ Moreover, the above NMR data, except for the glucose part, were similar to $1 \beta, 6 \beta$-dihydroxy-7-epi-eudesm3 -ene isolated from Pluchea dioscoridis. ${ }^{13}$ The differences were the chemical shifts at C-1, C-6, and C-9 : $\delta_{\mathrm{C}-1}=79.6, \delta_{\mathrm{C}-6}=$ 76.6 and $\delta_{\mathrm{C}-9}=81.3$ in 1 , and $\delta_{\mathrm{C}-1}=76.6, \delta_{\mathrm{C}-6}=68.4$ and $\delta_{\mathrm{C}-9}=$ 35.3 in $1 \beta, 6 \beta$-dihydroxy-7-epi-eudesm-3-ene, ${ }^{13}$ implying that 1 was glycosylated at C-6 and oxygenated at C-9. The coupling constant $(J=7.5 \mathrm{~Hz})$ of the anomeric proton at $\delta_{\mathrm{H}}=4.36$ of
D-glucose was in the $\beta$-form. ${ }^{14}$ The glycosidic position was established by $\mathrm{HMBC}$, with a long-range correlation observed between $\mathrm{H}-1^{\prime}\left(\delta_{\mathrm{H}}=4.36, \mathrm{~d}, J=7.5 \mathrm{~Hz}\right)$ and $\mathrm{C}-6\left(\delta_{\mathrm{C}}=76.6\right)$ (Figure 1). Thus, the structure of 1 was 1,6,9-trihydroxy-transeudesm-3-ene-6- $O-\beta$-D-glucopyronoside. The configuration of the hydroxyl group at C-1 was $\beta$-form based on the $J$ value $\left(\delta_{\mathrm{C}}=3.69 \text {, dd, } J=11.5,6.3 \mathrm{~Hz}\right)^{15,16}$ and NOESY spectrum (Figure 1). The configurations of hydroxyl groups at C-6 and C-9 were $\beta$ - and $\alpha$-forms, respectively, based on the NOESY correlations: the correlation of H-6 with H-5 (not with H-7), and the correlations of $\mathrm{H}-9$ with $\mathrm{H}-7$ and $\mathrm{H}-14$ (Figure 1). The proposed structure of 1 was in accordance with ${ }^{1} \mathrm{H}-{ }^{1} \mathrm{H} C O S Y$, HMQC, HMBC, and NOESY spectra. Therefore, the structure of 1 was $1 \beta, 6 \beta, 9 \alpha$-trihydroxy-trans-eudesm-3-ene-6-O- $\beta$-Dglucopyranoside.

Compound 2 was obtained as colorless gum with a molecular formula of $\mathrm{C}_{21} \mathrm{H}_{36} \mathrm{O}_{9}$ from the $[\mathrm{M}+\mathrm{Na}]^{+}$peak at $\mathrm{m} / \mathrm{z} 455.2259$ (calcd. for $\mathrm{C}_{21} \mathrm{H}_{36} \mathrm{O}_{9} \mathrm{Na}: 455.2257$ ) in the positive-ion HRFABMS. The IR spectrum indicated that 2 possessed a hydroxy $\left(3382 \mathrm{~cm}^{-1}\right)$ and a $\mathrm{C}=\mathrm{C}$ double bond $\left(1658 \mathrm{~cm}^{-1}\right)$. The NMR spectra of 2 were similar to those of compound 1, except for an additional oxygenated carbon signal in the ${ }^{13} \mathrm{C}$-NMR spectrum of 2; four oxygenated carbon signals $\left(\delta_{\mathrm{C}} 81.1,80.5,79.5\right.$ and 72.8 ) exist in 2 , with only three oxygenated carbon signals $\left(\delta_{\mathrm{C}}\right.$ $81.3,79.6$ and 76.6) in $\mathbf{1}$. The coupling pattern of methyl protons at $\mathrm{C}-12$ and $\mathrm{C}-13$ in the ${ }^{1} \mathrm{H}-\mathrm{NMR}$ spectrum was different $\left[\delta_{\mathrm{H}}=1.00(\mathrm{~d}), 0.95(\mathrm{~d}), J=6.3 \mathrm{~Hz}\right.$ in $1 ; \delta_{\mathrm{H}}=1.36(\mathrm{~s}), 1.25(\mathrm{~s})$ in 2]. The position of the hydroxylated carbon at $\delta_{\mathrm{C}}=72.8$ was

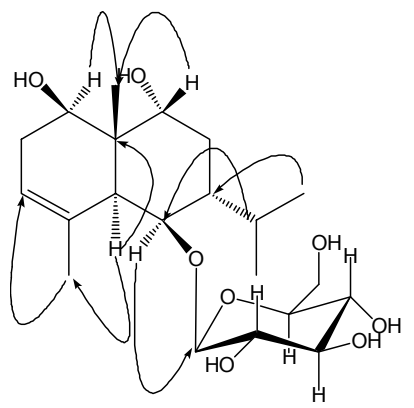

(a)

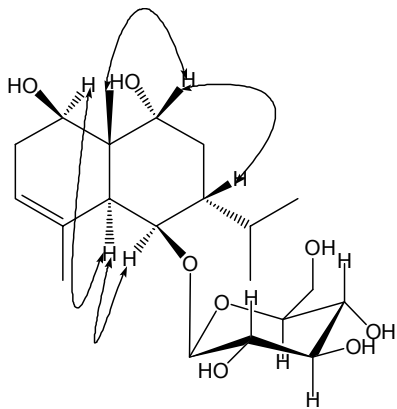

(b)
Figure 1. Key HMBC ( $\neg$ ) (a) and NOESY ( correlations of $\mathbf{1}$. 


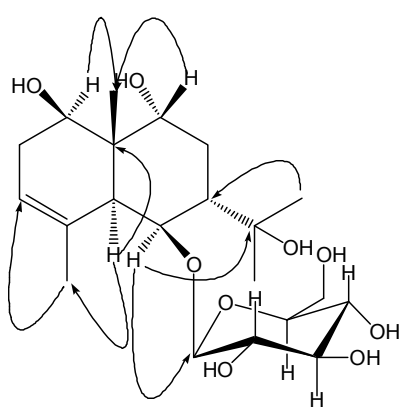

(a)

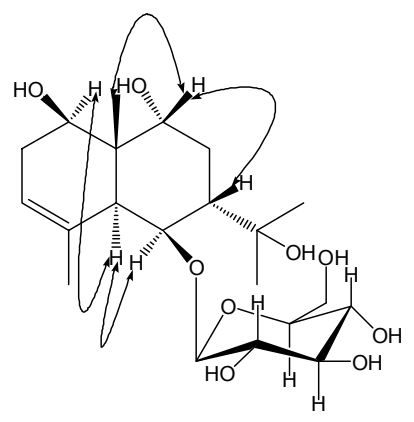

(b)
Figure 2. Key HMBC ( $\neg$ ) (a) and NOESY ( $\neg$ ) (b) correlations of 2 .

established by HMBC (Figure 2). The relative stereochemistry was the same as $\mathbf{1}$ based on the NMR data (chemical shifts and $J$ values) and reconfirmed by the NOESY spectrum (Figure 2). Thus, the structure of compound 2 was $1 \beta, 6 \beta, 9 \alpha, 11$-tetrahydroxy-trans-eudesm-3-ene-6-O- $\beta$-D-glucopyranoside.

Cytotoxic activities of the isolated compounds (1-12) were evaluated against A549, SK-OV-3, SK-MEL-2, and HCT15 human tumor cell lines in vitro using the SRB assay. Compounds 7, 9 and 12 showed moderate cytotoxicity against A549, SKOV-3, SK-MEL-2 and HCT15 cells, with ED 50 values of 7: 9.11, 9.26, 5.94, 8.32 ; 9: 12.07, 11.36, 7.53, $13.51 ; 12$ : 17.92, $15.04,10.83,17.40 \mu \mathrm{M}$, respectively, but other compounds did not $\left(\mathrm{ED}_{50}>30 \mu \mathrm{M}\right)$.

\section{Experimental Section}

General Procedures. All melting points were determined on a Gallenkamp melting point apparatus and are uncorrected.

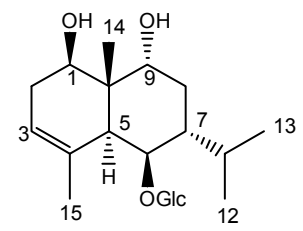

(1)
Optical rotations were measured on a JASCO P-1020 Polarimeter. UV spectra were obtained using a Shimadzu UV-1601 UV/Visible spectrophotometer (Shimadzu Co.). NMR spectra were recorded on a Varian UNITY INOVA 500 NMR and Bruker Avance 500 NMR spectrometer. FAB-MS data were obtained on a JEOL JMS700 mass spectrometer. Preparative HPLC was performed using a Gilson 306 pump, Shodex refractive index detector, and either an Apollo silica $5 \mu$ column $(250 \times 22 \mathrm{~mm})$ or an Econosil ${ }^{\circledR} \mathrm{RP}-1810 \mu$ column $(250 \times 22 \mathrm{~mm})$. Silica gel 60 (Merck, 70 - 230 mesh and 230 - 400 mesh) was used for column chromatography. TLC was performed with Merck precoated silica gel $\mathrm{F}_{254}$ plates and RP- $18 \mathrm{~F}_{254 \mathrm{~s}}$ plates. The packing material in the molecular sieve column chromatography was Sephadex LH-20 (Pharmacia Co.). Low pressure liquid chromatography was performed over Merck LiChroprep Lobar ${ }^{\circledR}$-A Si $60(240 \times 10 \mathrm{~mm})$ or LiChroprep Lobar ${ }^{\circledR}$-A RP-18 $(240 \times$ $10 \mathrm{~mm}$ ) columns with an FMI QSY-0 pump (ISCO).

Plant Materials. The flower parts of Gymnaster koraiensis (Nakai) Kitamura (Compositae) (5 kg) were collected at Pyeongchang in Gangwon province, Korea, in August, 2006. A voucher specimen of the plant (SKK-07-006) was deposited at the College of Pharmacy in Sungkyunkwan University.

Test for Cytotoxicity in vitro. A sulforhodamine B bioassay (SRB) was used to determine compound cytotoxicity against four human cancer cell lines ${ }^{17}$ in vitro at the Korea Research Institute of Chemical Technology. The tumor cell lines were A549 (non small cell lung adenocarcinoma), SK-OV-3 (ovarian cancer cells), SK-MEL-2 (skin melanoma), and HCT15 (colon cancer cells). Doxorubicin was used as the positive control. The cytotoxicity in $\mathrm{ED}_{50}$ of doxorubicin against A549, SK-OV-3, SK-MEL-2, and HCT15 were 0.001, 0.011, 0.001 and 0.027 $\mu \mathrm{M}$, respectively.

Extraction and Isolation. The half-dried flower parts of $G$.

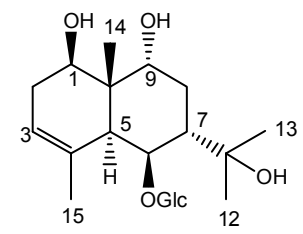

(2)

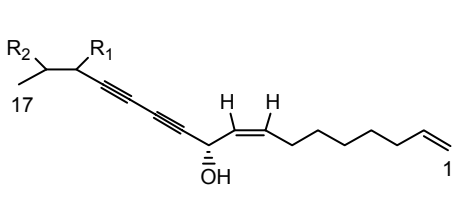

(3) $\mathrm{R}_{1}, \mathrm{R}_{2}:-\mathrm{O}-$ (4) $\mathrm{R}_{1}, \mathrm{R}_{2}: \mathrm{OH}$<smiles>[R]c1cc(O)c2c(c1)OC(c1ccc(O)cc1)CC2=O</smiles>

(8)

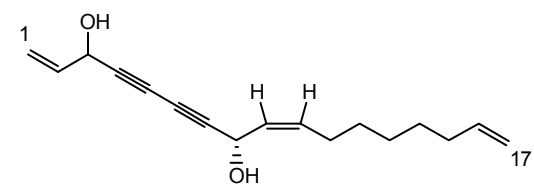

(5)<smiles>[R]c1cc(O)c2c(=O)c([R])c(-c3ccc(O)c([R])c3)oc2c1</smiles>

(7) $\mathrm{R}_{1}: \mathrm{H}$

(9) $\mathrm{R}_{1}: \mathrm{H}$

$\mathrm{R}_{2}: \mathrm{OH}, \quad \mathrm{R}_{3}: \mathrm{H}$

(10) $\mathrm{R}_{1}:$-OGlc, $\quad \mathrm{R}_{2}: \mathrm{OH}, \mathrm{R}_{3}: \mathrm{OH}$

(11) $\mathrm{R}_{1}$ :-OGIcA, $\mathrm{R}_{2}: \mathrm{OH}, \quad \mathrm{R}_{3}:-\mathrm{OCH}_{3}$

(12) $R_{1}: H, \quad R_{2}:$-OGlc, $R_{3}: H$

Figure 3. Structures of isolated compounds (1-12). 
Table 1. NMR data for compounds $\mathbf{1}$ and $\mathbf{2}$

\begin{tabular}{|c|c|c|c|c|}
\hline \multirow{2}{*}{ Position } & \multicolumn{2}{|l|}{1} & \multicolumn{2}{|l|}{2} \\
\hline & $\delta_{\mathrm{H}}{ }^{a}$ & $\delta_{\mathrm{c}}^{b}$ & $\delta_{\mathrm{H}}{ }^{a}$ & $\delta_{\mathrm{c}}{ }^{b}$ \\
\hline 1 & $3.69(\mathrm{dd}, 11.5,6.3)$ & 79.6 & $3.69(\mathrm{dd}, 9.7,6.3)$ & 79.5 \\
\hline $2 \alpha$ & $2.07(\mathrm{~m})$ & 32.6 & $2.09(\mathrm{~m})$ & 32.3 \\
\hline $2 \beta$ & $2.04(\mathrm{~m})$ & & $2.07(\mathrm{~m})$ & \\
\hline 3 & 5.28 (br. s) & 120.6 & 5.23 (br. s) & 120.9 \\
\hline 4 & & 136.4 & & 136.5 \\
\hline 5 & $1.81(\mathrm{~m})$ & 52.1 & $1.81(\mathrm{~m})$ & 52.5 \\
\hline 6 & 4.38 (br. s) & 76.6 & 4.45 (br. s) & 80.5 \\
\hline 7 & $1.71(\mathrm{~m})$ & 51.9 & $1.47(\mathrm{~m})$ & 51.9 \\
\hline $8 \alpha$ & $1.81(\mathrm{~m})$ & 30.8 & $2.12(\mathrm{~m})$ & 27.9 \\
\hline $8 \beta$ & $1.81(\mathrm{~m})$ & & $1.79(\mathrm{~m})$ & \\
\hline 9 & $3.71(\mathrm{dd}, 10.4,5.7)$ & 81.3 & $3.77(\mathrm{dd}, 12.0,4.6)$ & 81.1 \\
\hline 10 & & 42.4 & & 42.4 \\
\hline 11 & $1.99(\mathrm{~m})$ & 28.9 & & 72.8 \\
\hline 12 & $1.00(\mathrm{~d}, 6.3)$ & 21.9 & $1.36(\mathrm{~s})$ & 29.3 \\
\hline 13 & $0.95(\mathrm{~d}, 6.3)$ & 21.9 & $1.25(\mathrm{~s})$ & 29.4 \\
\hline 14 & $1.10(\mathrm{~s})$ & 9.3 & $1.13(\mathrm{~s})$ & 9.6 \\
\hline 15 & $1.80(\mathrm{~s})$ & 21.8 & $1.73(\mathrm{~s})$ & 22.2 \\
\hline $1^{\prime}$ & $4.36(\mathrm{~d}, 7.5)$ & 104.6 & $4.36(\mathrm{~d}, 7.5)$ & 105.4 \\
\hline $2^{\prime}$ & 3.14 (br. t, 8.5) & 76.1 & $3.16(\mathrm{~m})$ & 75.8 \\
\hline $3^{\prime}$ & $3.33(\mathrm{~m})$ & 78.4 & $3.37(\mathrm{~m})$ & 78.2 \\
\hline $4^{\prime}$ & $3.20(\mathrm{~m})$ & 72.1 & $3.27(\mathrm{~m})$ & 72.3 \\
\hline $5^{\prime}$ & $3.29(\mathrm{~m})$ & 77.3 & $3.23(\mathrm{~m})$ & 77.2 \\
\hline $6 a^{\prime}$ & $3.66(\mathrm{dd}, 12.0,7.5)$ & 63.4 & $3.65(\mathrm{dd}, 12.0,7.5)$ & 63.8 \\
\hline $6 b^{\prime}$ & $3.86(\mathrm{dd}, 12.0,3.0)$ & & $3.81(\mathrm{dd}, 12.0,3.0)$ & \\
\hline
\end{tabular}

${ }^{a b}$ Assignments were performed with DEPT, COSY, HMQC, HMBC and NOESY. Measured in $\mathrm{CD}_{3} \mathrm{OD}$.

koraiensis $(5.0 \mathrm{~kg})$ were extracted with $100 \% \mathrm{EtOH}$ at room temperature and evaporated under reduced pressure to give residue $(250 \mathrm{~g})$, which was dissolved in water $(800 \mathrm{~mL} \times 3)$ and solvent partitioned to give hexane $(27 \mathrm{~g})$ and $\mathrm{BuOH}$ fractions $(85 \mathrm{~g})$. The hexane fraction $(27 \mathrm{~g})$ was separated over a silica gel column using a gradient solvent system of hexane : EtOAc $(5: 1-1: 1)$ as the eluent to yield seven fractions (H1 H7). Fraction H5 (1.8 g) was also subjected to silica gel column chromatography (hexane : EtOAc $=5: 1-1: 1$ ) and was purified with a silica gel prep HPLC with hexane : EtOAc $(2.5: 1)$ to yield compound $\mathbf{3}(75 \mathrm{mg})$. Fraction H3 (3.0 g) was also subjected to silica gel column chromatography (hexane : EtOAc = $7: 1-2: 1)$ and was purified with a silica gel prep HPLC with hexane : $\mathrm{CHCl}_{3}$ : EtOAc $(9: 9: 1)$ to yield compounds 4 (14 $\mathrm{mg}), 5(10 \mathrm{mg})$ and $\mathbf{6}(5 \mathrm{mg})$. The $\mathrm{BuOH}$ fraction $(85 \mathrm{~g})$ was separated over a silica gel column with a solvent system of $\mathrm{CHCl}_{3}: \mathrm{MeOH}:$ Water $(35: 10: 1-10: 5: 1)$ to give nine fractions (B1 - B9). Fraction B1 (6.0 g) was also subjected to silica gel column chromatography $\left(\mathrm{CHCl}_{3}: \mathrm{MeOH}:\right.$ Water $=$ $35: 10: 1)$ and was purified with a silica gel prep HPLC with $\mathrm{CHCl}_{3}: \mathrm{MeOH}(6: 1)$ to yield compounds $1(60 \mathrm{mg})$ and 2 (70 $\mathrm{mg})$. Fraction B2 (6.8 g) was also subjected to silica gel column chromatography $\left(\mathrm{CHCl}_{3}: \mathrm{MeOH}:\right.$ Water $\left.=35: 10: 1\right)$ and was purified with a silica gel prep $\mathrm{HPLC}$ with $\mathrm{CHCl}_{3}: \mathrm{MeOH}(12: 1)$ to yield compounds $7(400 \mathrm{mg}$ ) and $\mathbf{8}(4 \mathrm{mg})$. Fraction B3 (600 mg) was also subjected to RP C-18 column chromatography $(20 \% \mathrm{MeCN})$ and was purified with a silica gel prep HPLC with $50 \% \mathrm{MeOH}$ to yield compound $9(6 \mathrm{mg})$. Fraction B5 $(1.2 \mathrm{~g})$ was also subjected to RP C-18 column chromatography $(30 \% \mathrm{MeOH})$ and was purified with a silica gel prep HPLC with $50 \% \mathrm{MeOH}$ to yield compound $\mathbf{1 0}(12 \mathrm{mg})$. Fraction B6 (1.6 g) was subjected to LH-20 column chromatography $\left(\mathrm{CH}_{2} \mathrm{Cl}_{2}: \mathrm{MeOH}=1: 1\right)$ and was purified with a silica gel prep HPLC with 30\% MeOH to yield compounds $11(12 \mathrm{mg}$ ) and $12(18 \mathrm{mg})$.

$1 \beta, 6 \beta, 9 \alpha-T r i h y d r o x y-t r a n s-e u d e s m-3-e n e-6-O$ - $\beta$-D-glucopyranoside (1): Colorless gum; $[\alpha]_{\mathrm{D}}^{25}:-19.6^{\circ}(c 0.1, \mathrm{MeOH})$; IR (KBr) $v_{\max } \mathrm{cm}^{-1}: 3386,2956,1650,1362,1079 \mathrm{~cm}^{-1} ;{ }^{1} \mathrm{H}-$, ${ }^{13} \mathrm{C}-\mathrm{NMR}$ : see Table 1.; HR FAB-MS (positive-ion mode) $\mathrm{m} / \mathrm{z}$ : $493.2306[\mathrm{M}+\mathrm{Na}]^{+}$.

$1 \beta, 6 \beta, 9 \alpha, 11-T e t r a h y d r o x y-t r a n s-e u d e s m-3-e n e-6-O-\beta-D-$ glucopyranoside (2): Colorless gum; $[\alpha]_{\mathrm{D}}^{25}:+2.66^{\circ}(c 0.1$, $\mathrm{MeOH})$; IR (KBr) $v_{\text {max }} \mathrm{cm}^{-1}: 3382,2925,1658,1361,1077 \mathrm{~cm}^{-1}$; ${ }^{1} \mathrm{H}-,{ }^{13} \mathrm{C}-\mathrm{NMR}$ : see Table 1. HR FAB-MS (positive-ion mode) $\mathrm{m} / \mathrm{z}: 455.2259[\mathrm{M}+\mathrm{Na}]^{+}$.

Acknowledgments. The authors would like to thank Mr. Do Kyun Kim, Dr. Eun Jung Bang, and Dr. Jung Ju Seo at the Korea Basic Science Institute for the measurements of NMR and mass spectra.

\section{References}

1. Ahn, D. K. Illustrated Book of Korean Medicinal Herbs; Kyo-Hak Publishing Co.: Korea, 1998; p 607.

2. Jung, H. J.; Min, B. S.; Park, J. Y.; Kim, Y. H.; Lee, H. K.; Bae, K. H. J. Nat. Prod. 2002, 65, 897.

3. Park, J. Y.; Min, B. S.; Jung, H. J.; Kim, Y. H.; Lee, H. K.; Bae, K. H. Chem. Pharm. Bull. 2002, 50, 685.

4. Dat, N. T.; Van Kiem, P.; Cai, X. F.; Shen, Q.; Bae, K. H.; Kim, Y. H. Arch. Pharm. Res. 2004, 27, 1106.

5. Lee, I. K.; Kim, K. H.; Ryu, S. H.; Lee, K. R. Heterocycles 2009 , $78,2827$.

6. Wang, Y.; Toyota, M.; Krause, F.; Hamburger, M.; Hostettmann, K. Phytochemistry 1990, 29, 3101.

7. Han, X. H.; Hong, S. S.; Hwang, J. S.; Lee, M. K.; Hwang, B. Y.; Ro, J. S. Arch. Pharm. Res. 2007, 30, 13.

8. Zhang, X. F.; Hung, T. M.; Phuong, P. T.; Ngoc, T. M.; Min, B. S.; Song, K. S.; Seong, Y. H.; Bae, K. H. Arch. Pharm. Res. 2006, 29, 1102.

9. Ibrahim, A. R. S. Phytochemistry 2000, 53, 209.

10. Oyama, K.; Kondo, T. Tetrahedron 2004, 60, 2025.

11. Han, J. T.; Bang, M, H.; Chun, O. K.; Kim, D. O.; Lee, C. Y.; Baek, N. I. Arch. Pharm. Res. 2004, 27, 390.

12. Needs, P. W.; Kroon, P. A. Tetrahedron 2006, 62, 6862.

13. Mahmoud, A. A. Phytochemistry 1997, 45, 1633.

14. Perkins, S. J.; Johnson, L. N.; Phillips, D. C. Carbohydr. Res. 1977, 59, 19.

15. Zhang, H. J.; Tan, G. T.; Santarsiero, B. D.; Mesecar, A. D.; Hung, N. V.; Cuong, N. M.; Soejarto, D. D.; Pezzuto, J. M.; Fong, H. H. S. J. Nat. Prod. 2003, 66, 609.

16. García-Granados, A.; Gutiérrez, M. C.; Rivas, F.; Arias, J. M.; Phytochemistry 2001, 58, 891.

17. Skehan, P.; Storeng, R.; Scudiero, D.; Monks, A.; McMahon, J.; Vistica, D.; Warren, J. T.; Bokesch, H.; Kenny, S.; Boyd, M. R. J. Natl. Cancer Inst. 1990, 82, 1107. 